\title{
Spatial variation of picoplankton communities along a cascade reservoir system in Patagonia, Argentina
}

\author{
M. Carolina Bernal, ${ }^{1 *}$ Lunhui Lu, ${ }^{2}$ Carmen Sabio y García, ${ }^{1}$ María Laura Sánchez, ${ }^{1}$ M. Solange Vera, ${ }^{1}$ Sol Porcel, ${ }^{1}$ \\ Rodrigo Sinistro, ${ }^{1}$ Zhe $\mathrm{Li},{ }^{2}$ Irina Izaguirre ${ }^{1}$
}

\begin{abstract}
${ }^{1}$ Departamento de Ecología, Genética y Evolución, IEGEBA (CONICET-UBA), Facultad de Ciencias Exactas y Naturales, Universidad de Buenos Aires, Buenos Aires, Argentina; ${ }^{2}$ Chongqing Institute of Green and Intelligent Technology, Chinese Academy of Sciences, Chongqing, China
\end{abstract}

\begin{abstract}
In this study we explored how picoplankton community structure and diversity varied along three cascade oligo-mesotrophic reservoirs of the Limay River (Patagonia, Argentina): Alicura, Piedra del Águila and Ramos Mexía. We analyzed the spatial changes, covering lotic and lentic stretches along a gradient of $262 \mathrm{~km}$ from Andes to steppe, and we also sampled the main affluent of the Limay River (Collon Cura). In all sampling sites the main limnological variables were measured, and the picoplankton abundance (autotrophic and heterotrophic) was analyzed by flow cytometry. The bacterial biodiversity was assessed using high throughput sequencing Illumina MiSeq. We expected an increase in the trophic state along this series of cascade reservoirs, which would determine spatial differences in the structure of the picoplankton communities. We also hypothesized that the lotic and lentic conditions along the system would influence the bacterial composition. The results showed a slight increase in trophic state together with an increase in overall picoplankton abundance downstream, towards Ramos Mexía Reservoir. Picocyanobacteria were represented by phycoerythrin-rich cells all along the system, in accordance to the pattern described for oligotrophic aquatic ecosystems. Multivariate analyses based on bacterial OTU composition and environmental variables showed a spatial ordination of sites following the trend of increasing trophic state downstream. Molecular analyses of bacterial OTU diversity also showed an increase in richness and a decrease in evenness at the lotic stretches, and the opposite pattern in the reservoirs, suggesting that water retention time may play a role in structuring the community composition.
\end{abstract}

\section{INTRODUCTION}

A great number of reservoirs around the world have been built for different purposes, such as provision of drinking water, irrigation, recreational activities, fish-farming, regulation of floods and hydroelectric power generation (McCully, 2001; Dudgeon, 2020). In Argentina hydroelectric power is currently responsible for one third of total energy production in the country (CAMMESA, 2017), and five of the main hydroelectric power stations are located in Patagonia, four of them belonging to the Comahue region (https://www.argentina.gob.ar/energia/energia-electrica/ hidroelectrica/centrales-hidroelectricas). The main reservoirs from the Comahue region are located on the Limay

Corresponding author: cbernal@ege.fcen.uba.ar

Key words: Cascade reservoirs; Patagonia; picoplankton; flow cytometry; bacterial biodiversity.

Received: 29 April 2021.

Accepted: 23 July 2021.

This work is licensed under a Creative Commons Attribution NonCommercial 4.0 License (CC BY-NC 4.0).

${ }^{\circ}$ Copyright: the Author(s), 2021

Licensee PAGEPress, Italy

J. Limnol., 2021; 80(3):2027

DOI: 10.4081 jlimnol.2021.2027 and Neuquén rivers, both of Andean origin, which flow in a west-east direction and meet in Neuquén to form the Río Negro River. Besides energy generation, these reservoirs are used for flood attenuation, recreational purposes, and as a supply of water for irrigation (CAMMESA, 2017). In spite of the benefits that reservoirs can provide, they can also be responsible of negative effects associated to the drastic changes in flow conditions to which lotic biota are adapted, and the alteration of the trophic conditions of the impounded section (Dudgeon, 2020). One of the main undesired effects is the eutrophication of the water body mainly due to the increment in water retention time and water temperature (Schindler, 2006). At mid-high latitudes, this process seems to occur necessarily when significant anthropogenic inputs of nutrients enter the reservoirs (McCartney et al., 2000). Moreover, the development of cyanobacterial algal blooms may be promoted in eutrophic conditions, especially in dry summers and with high water retention times (Lampert and Sommer, 2007; Rangel et al., 2012; O'Farrell et al., 2019).

Many river-systems, such as the one here studied, function as an alternating series of lentic and lotic reaches due to multiple impoundments. The potential impacts on different abiotic and biotic parameters in reservoirs located at different reaches of a river were conceptualized by the serial discontinuity model (Ward and Stanford, 1983) and upstream and downstream impacts were also described by McCartney et al. (2000).

Since the 80 's and 90's decade different studies have 
been conducted in the reservoirs of the Limay River system. Labollita and Pedrozo (1997) analyzed the main limnological features of four cascade reservoirs (Alicura, Piedra del Águila, Ramos Mexía and Arroyito), and found that the leading regulating factor of their trophic state was the availability of nutrients. Alicura has been described as an oligotrophic water body with low nutrient concentrations, high transparency, and high oxygen content (Baffico and Pedrozo, 1996; Secretaría de Energía, 2003), which mixes in winter (Labollita and Pedrozzo, 1997). Piedra del Águila has also been characterized as oligotrophic with a mixing period in winter (Labollita and Pedrozzo, 1997). In Ramos Mexía, where El Chocón dam is located, several studies have addressed the main physical, chemical, and biological aspects (e.g., Land de Castello, 1981; Quirós et al., 1985; Mariazzi et al., 1991; Baigún and Marinone, 1995; Zunino and Díaz, 2000). This reservoir has been classified as oligo-mesotrophic due to its chlorophyll $a(\mathrm{Chl} a)$ values (Secretaría de Energía, 2003) and with a constant mixing period (Labollita and Pedrozo, 1997). Besides the data reported in published papers, a regular monitoring of physical and chemical parameters and Chla values in the reservoirs of the Limay River has been carried out by the Interjurisdictional Authority of Limay, Neuquén and Río Negro basins (AIC) since 1993 (Labollita and Pedrozo, 1997).

Although published papers on the planktonic communities of the reservoirs located in the Limay system are relatively scarce or fragmentary, within the framework of the permanent monitoring carried out by AIC, samples were collected in the 1990's in open-water sampling sites within the vicinity of the dams for the assessment of the phytoplankton abundance. The main information obtained about the phytoplankton structure was summarized in the review published by Casco et al. (2014). According to this monitoring, after the biotic stabilization of the reservoirs, which occurred several years after their creation, blooms of cyanobacteria were reported in certain zones, particularly in Ramos Mexía Reservoir, during the warm season (Casco et al., 2014 and cites therein). On the other hand, Díaz (1994) conducted a seasonal study of the phytoplankton and its relation with the environmental factors in several Patagonian lakes, including Alicura Reservoir. Regarding photosynthetic picoplankton, Zunino and Díaz (2000) reported the first data of abundance of this fraction for Alicura and Ramos Mexía reservoirs, among other Patagonian water bodies. These authors found that the picocyanobacteria (Pcy) were up to two orders of magnitude more numerous than picoeukaryotes (Peuk) in summer and that in the oligotrophic water bodies the phycoerithrin-rich (PE-rich) Pcy were more abundant than the phycocyanin-rich (PC-rich) Pcy. In another study, Di Siervi et al. (1995) monthly analyzed the heterotrophic bacterial and primary production in Ramos Mexía during one year and found that maximum rates of secondary production coincided with those of primary production, with peaks in summer.

For Ramos Mexía, Mariazzi et al. (1991) also provided data of the phytoplankton community and primary production together with the main physical and chemical features, reporting that the reservoir is characterized by soft water, poor nutrients and a low transparency that greatly diminishes primary production. In Alicura, trout farming (Oncorhynchus mykiss) began in 1989, thus most of the studies in this reservoir have been oriented to the impacts related to aquaculture, mainly due to the increment in nutrients and organic matter, which may alter the trophic state and algal species composition (Baffico and Pedrozo, 1996; Díaz et al., 2001; Temporetti et al., 2001). For Piedra del Águila Reservoir, until now no studies of the planktonic communities had been published.

The relevance of the picoplanktonic fraction in oligotrophic environments - such as the system dealt with here - has been recognized a long time ago (e.g., Stockner and Antia, 1986; Porter et al., 1988; Cotner and Biddanda, 2002) and more recently studies on both their autotrophic and heterotrophic fraction have been made (e.g. Callieri, 2008; Bastidas Navarro et al., 2009). In oligotrophic water bodies Pcy may exceed $70 \%$ of the total photosynthetic biomass (Vörös et al., 1998), and photosynthetic picoplankton may contribute up to $70 \%$ of total primary production (Stockner and Antia, 1986; Callieri et al. 2012). In spite of this, with the exception of the few studies above mentioned, there is very scarce information about picoplankton of the Patagonian reservoirs, whereas many more studies have been conducted in natural Patagonian lakes. In particular, Callieri et al. (2007) studied production and biomass of picophytoplankton and larger autotrophs in Andean ultraoligotrophic lakes during summer stratification and found a strong photoinhibition effect of high photosynthetically active radiation (PAR) and UV-A at surface levels for both size fractions, but a higher photosynthetic efficiency for picophytoplankton with increasing depth. This study also revealed a decreasing trend of picophytoplankton biomass but an increase in its relative contribution to total phytoplankton biomass with decreasing trophic state. Later, Caravati et al. (2010) analyzed Pcy assemblages in ultraoligotrophic Andean lakes and found a high $\beta$ diversity, a distinctive vertical distribution of operational taxonomic units (OTUs) and habitat specificity of some OTUs. Schiaffino et al. (2013) studied picoplankton abundance and cytometric group diversity in lakes along a trophic and latitudinal lake gradient in Southern Patagonia and found that environmental factors were more important than latitude in defining picoplankton community structure.

Some studies conducted on single catchments covering wide ranges of network positioning and hydrologic condi- 
tions have shown that hydrology and associated mass effects were the main drivers of community structure (NiñoGarcía et al., 2016 and cites therein). However, in a system such as a river with multiple impoundments, where the lotic to lentic state passage is not gradual, but alternate, studies on the drivers of picoplankton community composition remain scarce (e.g., Wang et al., 2008; Wang et al., 2018; Chen et al., 2020; Reis et al., 2020; Yang et al., 2020), and until now were null in our study area.

In this paper we analyzed the spatial variation in the picoplanktonic cytometric populations and the diversity of bacterial OTUs along the Limay River system, including sampling sites at the lotic sections and at the main reservoirs (Alicura, Piedra del Águila and Ramos Mexía). We also evaluated the relationship between picoplankton community structure and the limnological variables, and we compared the bacterial diversity at lotic and lentic stretches of the studied system.

Assuming that in a series of cascade reservoirs there would be a downstream increase in trophic state, we hypothesized that this determines: a) spatial differences in the picoplankton communities, with an increase in picoplankton abundance downstream, towards Ramos
Mexía Reservoir; b) a change in the proportion of PE-rich and PC-rich Pcy. On the other hand, given the alternation of lotic and lentic sections along the studied system, we also hypothesized that: c) the bacterial biodiversity is influenced by the lotic and lentic conditions, resulting in contrasting patterns in these stretches.

\section{METHODS}

\section{Study site}

The study was conducted in the Limay River system $\left(39^{\circ} 15^{\prime}-40^{\circ} 45^{\prime} \mathrm{S} ; 6^{\circ} 44^{\prime}-71^{\circ} 06^{\prime} \mathrm{W}\right)$. We covered a distance of about $262 \mathrm{~km}$, with eleven sampling sites including the main channel (Limay River), three cascade reservoirs (Alicura, Piedra del Águila and Ramos Mexía) and the main tributary of Limay River (Collon Cura River).

The geographic position of each site was obtained with a GPS (geographic positioning system; Garmin, KS, USA), and is shown in Fig. 1. Altitude at the sampling sites decreases downstream, ranging from 706 to $243 \mathrm{~m}$ asl. Tab. 1 shows the main morphometric and hydrological features of the three studied reservoirs.

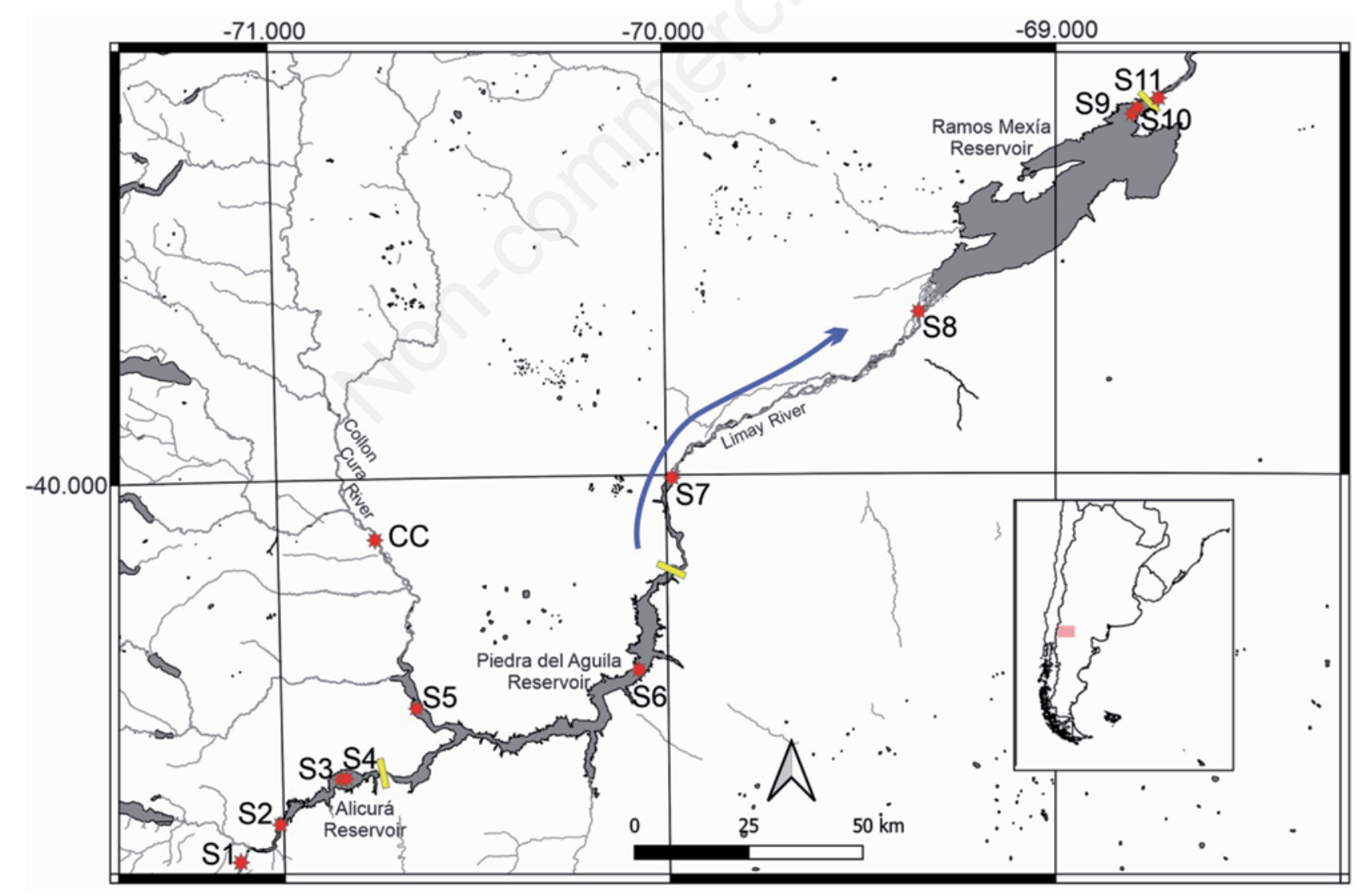

Fig. 1. Sampling sites (red dots) along the Limay River (S1 to S11) and Collon Cura affluent (CC). Blue arrow indicates downstream direction. Each dam is indicated with a yellow bar. 
The cascade reservoirs system here studied is subject to an environmental gradient, extending from a transition zone between the Andean Forest and the herbaceous-shrub steppe, with a semi-arid climate and mean annual rainfall of $500 \mathrm{~mm}$ at the zone of Alicura Reservoir, to a shrub steppe with predominantly arid climate and a mean annual rainfall of around $130 \mathrm{~mm}$ at the zone of Ramos Mexía Reservoir (Secretaría de Energía, 2003). Ranges of mean temperatures at the zone of Alicura are $-0.6-6.9^{\circ} \mathrm{C}$ (July) and 6.6-22.6 $6^{\circ} \mathrm{C}$ (January), whereas at the zone of Ramos Mexía are $0.2-12.9^{\circ} \mathrm{C}$ (July) and $15.5-31.9^{\circ} \mathrm{C}$ (January). Meteorological data were obtained from the Argentinian Meteorological Service (https://www.smn.gob.ar).

\section{Physical and chemical variables}

Samplings took place in summer, between 9-18 January 2019. In the reservoirs, samples were taken at the pelagic zone using a boat where maximum depth was around $4 \mathrm{~m}$, whereas in the lotic sections they were taken near the littoral zone by using waders. In all sites samples were collected within the euphotic zone at the subsurface layer ( 30-50 cm depth). Physical and chemical variables were measured in situ by means of portable sensors. Conductivity and $\mathrm{pH}$ were obtained using a Horiba D-54 sensor (Horiba, Kyoto, Japan); dissolved oxygen and temperature were measured with a Hach HQ30d sensor, and a profile of these two variables was obtained at sampling sites of the reservoirs to detect stratification. A LICOR radiometer equipped with a quantum submersible spheric sensor (Li193 SA; Li- Cor PAR, NE, USA) was used to measure photosynthetically active radiation (PAR) at different depths in the water column. Vertical attenuation coefficient of PAR $\left(\mathrm{Kd}_{\mathrm{PAR}}\right)$ was calculated for the three studied reservoirs according to Kirk (1994). Transparency was estimated with a Secchi disc only at the sampling sites within the reservoirs, whereas turbidity was measured at all sites with a Hach 2100Q IS turbidimeter. Samples for chemical analy- ses were preserved in plastic bottles previously rinsed with $\mathrm{HCl} 2 \%$ and MilliQ water and transported to the laboratory in cold and dark conditions. A group of samples was immediately filtered through Whatman ${ }^{\mathbb{B}} \mathrm{GF} / \mathrm{F}$ filters; the material retained on the filters was used for Chl $a$ analyses and the filtrated water for dissolved organic carbon (DOC) determinations. Another group of samples (not filtered) were preserved acidified ( $\mathrm{pH}$ 2) for later total phosphorus (TP) and total nitrogen (TN) determinations following acidic digestion (Valderrama, 1981). Filters for Chl $a$ determinations were transported to the laboratory in liquid nitrogen. Pigments were extracted using acetone, and Chla concentration was analyzed by spectrophotometry. Calculations of Chla concentrations were based on equations by Marker et al. (1980) and corrected for phaeopigments. Samples for the determination of DOC were analyzed in a Shimadzu TOC-5000 analyzer following recommendations of Sharp et al. (1993). In order to obtain the concentration of total particulate solids (bio and abioseston), another set of subsamples were filtered through previously dried and weighed $\mathrm{GF} / \mathrm{C}$ filters, which were then dried and reweighed in order to obtain the concentration of total particulate solids (bio and abioseston).

\section{Picoplankton}

Samples were also taken within the euphotic zone at the subsurface layer in all sites. The abundances of photosynthetic picoplankton (PPP) and bacterioplankton were analyzed using flow cytometry. A volume of $3.6 \mathrm{ml}$ of each sample was fixed in cryovials containing $0.4 \mathrm{ml}$ cold paraformaldehyde + glutaraldehyde $(10 \%$ final concentration), transported in liquid nitrogen to the laboratory and stored at $-80^{\circ} \mathrm{C}$ until analysis. At the University of Buenos Aires samples were analyzed in a FACSAria II (Becton Dickinson) flow cytometer equipped with a standard $15 \mathrm{~mW}$ blue argon-ion (emission at $488 \mathrm{~nm}$ ) laser and a red diode laser $(635 \mathrm{~nm})$. For the analysis of het-

Tab. 1. Main morphometric and hydrological features of the three studied reservoirs of the Limay River system. Data obtained from Dölling (2013) and https://www.argentina.gob.ar/orsep/registro-de-presas-fiscalizadas

\begin{tabular}{|c|c|c|c|}
\hline Reservoir name & Alicura & Piedra del Águila & Ramos Mexía \\
\hline Year completed (fully impounded) & 1984 & 1993 & 1973 \\
\hline Annual water level variations (m) & 5 & 7 & 3.5 \\
\hline Annual hydraulic retention time (days) & 138.7 & 204.4 & 427.1 \\
\hline Mean depth & 48.4 & 41.3 & 24.7 \\
\hline Maximum depth & 110 & 120 & 60 \\
\hline Full reservoir volume $\left(\mathrm{km}^{3}\right)$ & 3.2 & 12.4 & 20.6 \\
\hline Surface $\left(\mathrm{km}^{2}\right)$ & 61 & 292 & 825 \\
\hline Perimeter $(\mathrm{km})$ & 215.6 & 783.6 & 565 \\
\hline Average annual flow $\left(\mathrm{m}^{3} \mathrm{~s}^{-1}\right)$ & 276 & 713 & 683 \\
\hline Maximum recorded flood flow $\left(\mathrm{m}^{3} \mathrm{~s}^{-1}\right)$ & 750 & 3000 & 4909 \\
\hline
\end{tabular}


erotrophic bacteria (HB) $4 \mathrm{ml}$ of SYBR Green ${ }^{\circledR}$ (Sigma Aldrich) (494/521) were added to $400 \mathrm{~mL}$ of sample and left in darkness and room temperature for 10 minutes to allow the DNA staining to take place. At least 100,000 events per sample were obtained, and fluorescent beads were added at a known concentration as internal standards. High nucleic acid-containing bacteria (HNA) and low nucleic acid-containing bacteria (LNA) were identified using the "side scatter light" (SSC) versus "green fluorescence of NA bound stains" (FL1) signals (Gasol et al., 1999; Bouvier et al., 2007). For the analysis of PPP, the same procedure was carried out without staining the samples. The cytometric populations were identified using SSC versus "blue laser-dependent red fluorescence" (FL3), "orange fluorescence" (FL2) versus FL3, and "red laser-dependent far red fluorescence" (FL4) versus FL3 (Olson et al., 1993). Cytograms were analyzed using the FlowJo software (7.6 version).

\section{Bacterioplankton biodiversity}

Samples were taken at the same sites and depth as for picoplankton quantification, and were transported to the field laboratory in plastic bottles previously rinsed with $\mathrm{HCl} 2 \%$ and MilliQ water, in cold and darkness. In order to analyze the molecular biodiversity of the bacterioplankton (fraction $<2 \mu \mathrm{m}$ ), samples were sequentially filtered by a nylon filter of $51 \mathrm{~mm}$ pore size followed by an $18 \mathrm{~mm}$ pore-sized one (both previously MilliQ water-rinsed); then the water was filtered through $47 \mathrm{~mm}$ diameter $0.22 \mu \mathrm{m}$ pore-sized polycarbonate filters (Millipore) to retain the picoplanktonic fraction. Each filter was preserved in a cryovial in liquid nitrogen and afterwards stored at $-80^{\circ} \mathrm{C}$ until DNA extraction. The extraction was carried out following the protocol described by Fernández Zenoff et al. (2006). DNA was amplified using the $341 \mathrm{~F}-805 \mathrm{R}$ primer set specific to the V3-V5 variable region of the $16 \mathrm{~S}$ subunit of ribosomal RNA (Herlemann et al., 2011). Samples were sequenced by Illumina MiSeq at Shanghai Majorbio BioPharm Technology, Co., Ltd. (Shanghai, China). The diversity of OTUs was analyzed in each case.

\section{Bioinformatic analysis of the sequences}

Raw paired-end Illumina sequences were quality-filtered using the Quantitative Insights Into Microbial Ecology (QIIME, ver. 1.8) program (Caporaso et al., 2010). Trimmed sequences were paired-end aligned using fastqjoin and screened for quality using the following criteria: quality score $\geq 35$ over a $50 \mathrm{nt}$ window, no ambiguous bases, homopolymers $\leq 8 \mathrm{nt}$, and primer and barcode matching with $100 \%$ identity. Only reads with exact barcodes and primers, unambiguous nucleotides and a minimum length of $300 \mathrm{bp}$ were retained and subjected to a de novo chimera detection using Uchime (Edgar et al.,
2011). Then, OTUs were clustered at $97 \%$ level similarity cutoff by UPARSE (7.1 version). RDP (Ribosomal Database Project) classifier retrained with Greengenes (http://greengenes.secondgenomes) was then used for taxonomy assignment of the OTUs to the lowest taxonomic level possible. The OTUs taxonomically assigned to Archaea and chloroplasts were eliminated from the analysis. Raw reads were deposited in the European Nucleotide Archive public database within the Project accession number ERP124551 (see Supplementary material 2 for sample accession numbers).

\section{Statistical analyses}

A Principal Component Analysis (PCA) was carried out in order to evaluate the ordination of sites according to physical and chemical variables, previously standardized in R (ver. 4.0, R Core Team, 2020) and RStudio environment (ver. 1.2.5042, RStudio Team, 2020) with Vegan packages (Oksanen et al., 2019).

OTU richness, diversity (Shannon and Simpson indexes) and evenness were calculated by using Past Software, ver. 4.03. A Non-Metric Multidimensional Scaling (NMDS) analysis using Bray-Curtis similarity index was performed in order to explore the samples ordination based on OTU composition, also through the Past Software, ver. 4.03.

A Redundance Analysis (RDA) was applied to analyze how much of the bacterial biodiversity variance (based on OTU composition) was explained by the environmental variables. We previously performed a Detrended Correspondence Analysis (DCA) in order to establish the distribution of the biological data. The analysis was performed excluding the rare OTUs $(<1 \%$ of the reads in all samples) and the matrix was transformed by Hellinger. The statistical significance of the first axis and all the axes was tested by Monte Carlo permutation test, and the significance of the environmental variables was assessed by forward selection. This analysis was also performed in $\mathrm{R}$ (ver. 3.4.4; R Core Team, 2018) and RStudio (ver. 1.2.5042, RStudio Team, 2020) with Vegan packages (Oksanen et al., 2019).

For each bacterial phylum, we calculated the Pearson correlation coefficient between its percentage abundance at each site and the proportion between HNA and LNA abundance (HNA/LNA) at each site, based on an analysis made by Read et al. (2015). For this we used the Hmisc package (Hollander and Wolfe, 1973; Press et al., 1988) in R.

\section{RESULTS}

\section{Limnological variables}

Spatial differences along the cascade reservoirs system were evident for several of the limnological variables an- 
alyzed (Tab. 2). Due to the relatively high transparency of the reservoirs, Secchi disk values were in all cases higher than the maximum depth measured at each sampling site (around $4 \mathrm{~m}$ ). In spite of this, a spatial pattern was observed for turbidity, which varied between 0.69 and 3 FNU, with a clear increasing trend downstream, towards the Ramos Mexía Reservoir. In coincidence, total suspended solids showed the same spatial tendency, varying from 0.5 to $2.8 \mathrm{mgL}^{-1}$, with the highest values at Ramos Mexía. Conductivity varied from 33.3 to $67 \mathrm{mScm}^{-1}$ with higher values from $\mathrm{S} 8$ to $\mathrm{S} 11$ (downstream sites). Chla values were in all sites quite low and typical of oligotrophic systems, varying from 0.31 to $2.14 \mu \mathrm{gL}^{-1}$, but the highest concentrations were also observed at Ramos Mexía. TP ranged from 0.01 to $0.154 \mathrm{mgL}^{-1}$, with highest concentration occurring at S6. Very low values of TN were observed in all sites $\left(0.02-0.06 \mathrm{mgL}^{-1}\right)$ and no spatial pattern was observed. $\mathrm{Kd}_{\mathrm{PAR}}$ values ranged from 0.21 to $1.03 \mathrm{~m}^{-1}$, for Alicura and Piedra del Aguila reservoirs respectively. DOC also showed the lowest value at Alicura $\left(0.3 \mathrm{mgL}^{-1}\right)$ and the highest one at Ramos Mexía $\left(1.2 \mathrm{mgL}^{-1}\right)$. Temperature varied between 14.5 and $21.3^{\circ} \mathrm{C}$ with a slight increase downstream. Well-oxygenated waters were observed all along the system, with dissolved oxygen concentrations varying from 8.78 to $9.91 \mathrm{mgL}^{-1}$. Stratification in temperature and dissolved oxygen was not detected in the water column at the considered depth range.

Spatial variation of the studied sites was also evidenced in the PCA analysis (Fig. 2). S1 and S2 were or- dinated towards higher values of $\mathrm{pH}$. S2 to $\mathrm{S} 7$ and $\mathrm{CC}$ were ordinated, in general, with higher values of TP and lower values of turbidity, while S8 was related to higher values of conductivity. S9 to S11 were ordinated towards higher values of Chla and turbidity. PC 1 explained 43.8 $\%$ of the variance, and the main variables related to this axis were turbidity (correlation $=0.95$ ), Chl $a$ (correlation $=0.87$ ), DOC (correlation $=0.71$ ) and conductivity (correlation $=0.62$ ). PC2 explained $21 \%$ of the variance and was more related to conductivity (correlation $=0.74$ ) and $\mathrm{pH}$ (correlation $=-0.73$ ).

\section{Biological analyses}

\section{Flow cytometry results}

The picoplankton fraction was dominated by heterotrophic bacteria (HB) over PPP at all sampling sites. HB was composed of both LNA and HNA. LNA in general dominated over HNA, with the exception of $\mathrm{CC}$ and S8 where the opposite occurred. Bacterioplankton abundances at each sampling site are shown in Fig. 3a. The spatial pattern shows a slight increase in total HB abundance from the source towards the mouth of the Limay River, and also when the river reaches the reservoirs, ranging from $2.71 \times 10^{5}$ cells $\mathrm{mL}^{-1}$ to $5.01 \times 10^{5}$ cells $\mathrm{mL}^{-1}$. On the other hand, Collon Cura presented the highest HB abundance $\left(6.54 \times 10^{5}\right.$ cells $\left.\mathrm{mL}^{-1}\right)$.

Photosynthetic picoplankton, composed of Peuk and Pcy, varied between $6.92 \times 10^{3}$ and $1.23 \times 10^{5}$ cells $\mathrm{ml}^{-1}$ in

Tab. 2. Data corresponding to the main environmental variables for each sampling site along the Limay River system obtained in summer 2019.

\begin{tabular}{|c|c|c|c|c|c|c|c|c|c|c|c|c|}
\hline & S1 & S2 & S3 & S4 & S5 & S6 & S7 & S8 & S9 & S10 & S11 & $\mathrm{CC}$ \\
\hline Latitude (S) & 40.7515 & 40.76005 & 40.57323 & 40.57265 & 40.34667 & 40.00491 & 39.68089 & 39.68089 & 39.29996 & 39.29379 & 39.25129 & 40.11971 \\
\hline Longitude (W) & 71.11295 & 71.01331 & 70.85052 & 70.84898 & 70.6629 & 70.10092 & 69.98409 & 69.34959 & 68.79261 & 68.78273 & 68.74136 & 70.74883 \\
\hline Altitude (m) & 701 & 705 & 701 & 717 & 590 & 628 & 453 & 380 & 362 & 370 & 311 & 625 \\
\hline $\begin{array}{l}\text { Subsuperficial water } \\
\text { temperature }\left({ }^{\circ} \mathrm{C}\right)\end{array}$ & 14.50 & 16.10 & 17.10 & 17.10 & 19.10 & 17.90 & 14.80 & 21.20 & 20.00 & 21.30 & 19.20 & 21.10 \\
\hline $\begin{array}{l}\text { Subsuperficial } \\
\text { dissolved oxygen } \\
\left(\mathrm{mgL}^{-1}\right)\end{array}$ & 9.38 & 9.15 & 9.14 & 9.14 & 8.95 & 9.25 & 9.78 & 9.50 & 8.91 & 9.08 & 9.24 & 9.40 \\
\hline $\mathrm{pH}$ & 8.62 & 8.20 & 8.10 & 8.10 & 8.20 & 8.40 & 8.10 & 8.17 & 8.14 & 8.25 & 8.30 & 7.86 \\
\hline $\begin{array}{l}\text { Conductivity } \\
\left(\mu \mathrm{Scm}^{-1}\right)\end{array}$ & 38.10 & 33.30 & 58.60 & 58.60 & 54.20 & 45.30 & 55.80 & 61.10 & 64.30 & 67.00 & 65.00 & 60.30 \\
\hline Total $\mathrm{P}\left(\mathrm{mgL}^{-1}\right)$ & 0.05 & 0.12 & 0.08 & 0.08 & 0.10 & 0.17 & 0.13 & 0.08 & 0.05 & 0.08 & 0.08 & 0.11 \\
\hline Total N $\left(\mathrm{mgL}^{-1}\right)$ & 0.03 & 0.06 & 0.02 & 0.02 & 0.03 & 0.02 & 0.04 & 0.03 & 0.04 & 0.05 & 0.03 & 0.03 \\
\hline $\mathrm{DOC}\left(\mathrm{mgL}^{-1}\right)$ & 0.50 & 0.80 & 0.30 & 0.30 & 0.80 & 0.50 & 0.80 & 1.00 & 0.70 & 1.20 & 1.10 & 1.00 \\
\hline $\mathrm{Kd}_{\mathrm{PAR}}$ & 1.09 & 0.21 & 0.47 & 0.47 & 0.67 & 1.03 & 0.45 & 0.36 & 0.89 & 0.51 & 1.28 & 0.67 \\
\hline Turbidity (FNU) & 0.75 & 1.28 & 0.69 & 0.69 & 0.69 & 0.74 & 1.01 & 1.71 & 2.61 & 2.71 & 3.00 & 0.81 \\
\hline Chla $a\left(\mu \mathrm{gL}^{-1}\right)$ & 0.71 & 0.61 & 0.41 & 0.41 & 0.31 & 0.41 & 0.70 & 0.71 & 2.14 & 1.32 & 1.32 & 0.41 \\
\hline $\begin{array}{l}\text { Total suspended solids } \\
\left(\mathrm{mgL}^{-1}\right)\end{array}$ & s 0.80 & 0.80 & 0.60 & 0.60 & 0.70 & 0.50 & 0.60 & 0.10 & 2.10 & 0.90 & 2.80 & 1.10 \\
\hline
\end{tabular}




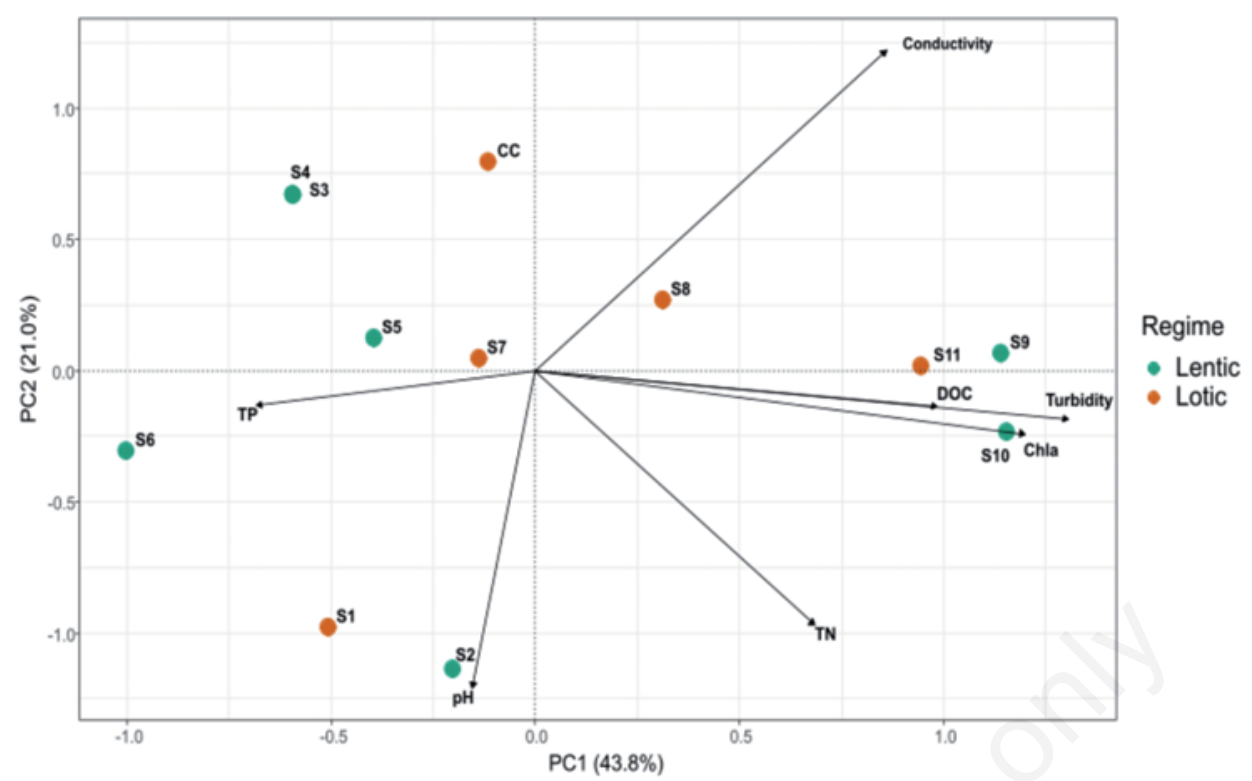

Fig. 2. Principal Component Analysis performed based on Chlorophyll a (Chla), dissolved organic carbon (DOC), Conductivity, Turbidity, total nitrogen (TN), total phosphorus (TP) and $\mathrm{pH}$ values for each sampling site. Sites with lentic regime are represented in green and those with lotic regime, in red.
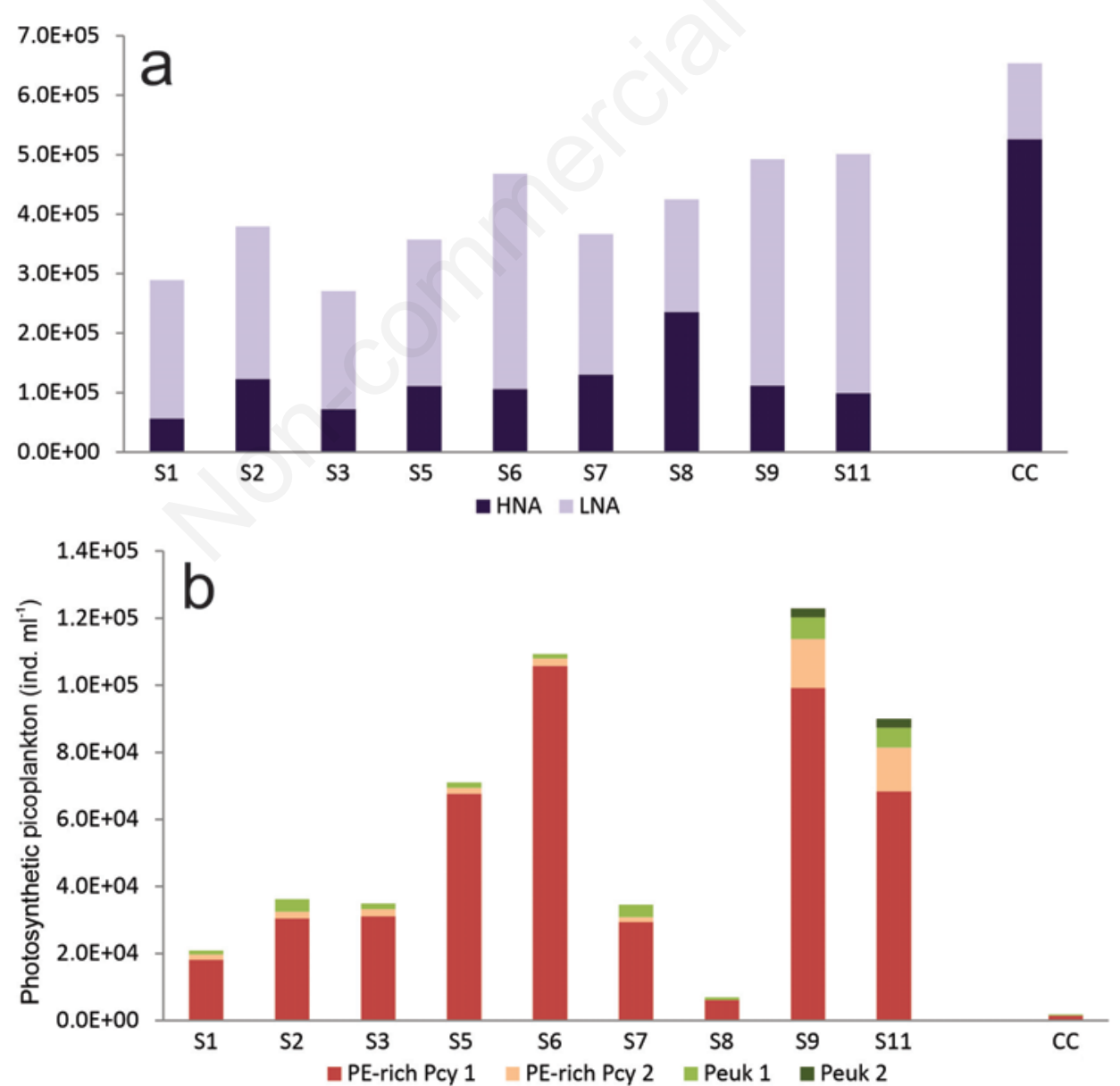

Fig. 3. Abundances of heterotrophic bacteria (a) and photosynthetic picoplankton (b) at each site. Flow cytometry analysis was not carried out for sites S4 and S10. 
the sites on Limay River, whereas the abundance was the lowest at Collon Cura $\left(1.84 \times 10^{3}\right.$ cells $\left.\mathrm{ml}^{-1}\right)$. Peuk were represented by one cytometric population at all sampling sites, except in Ramos Mexía Reservoir and downstream of this reservoir (S11), where a second population was present, Peuk2 (Figs. 3b and 4). On the other hand, Pcy were represented by one or two cytometric populations of PE-rich Pcy (Fig. 4). PE-rich Pcy 1 always dominated over PE-rich Pcy 2 and Peuk; the percentage of PE-rich Pcy 1 with respect to PPP ranged between 76 and 97\%. No PC-rich Pcy were identified in any sampling site; we are aware that fixation can underestimate PCs, so we cannot totally exclude their presence. It is noteworthy that, like bacterioplankton, the total abundance of PPP and PErich Pcy seems to increase when the river reaches the reservoirs, and also in this case an overall increase in PPP abundance is observed downstream along the system. Moreover, the proportion of Peuk increased slightly at S2 and towards Ramos Mexía Reservoir (Fig. 3b).

\section{Bacterioplankton biodiversity}

A total of 1319 OTUs were obtained from 463297 sequences after all filtration steps. The final number of reads was relatively similar between the 12 sampling sites -rang- ing from 35283 to 40604 - and a further normalization step was considered unnecessary (Supplementary material 1). At phylum level, these OTUs were classified into a total of 27 phyla. The percentages of these phyla differed among studied sites along the spatial gradient in the Limay River (Fig. 5). Actinobacteria, Bacteroidetes, Proteobacteria, Cyanobacteria and Verrucomicrobia were present at all sites. Actinobacteria was the dominant phylum at all sampling points, ranging from 40 to $65 \%$ of the sequences, except in CC, where Bacteroidetes represented $67 \%$ of the sequences, and S8, where Actinobacteria, Bacteroidetes and Proteobacteria were equally represented. S8 also presented the highest proportion of Proteobacteria (31\%) compared to the rest of the studied sites. In relation to Acidobacteria, the highest proportions were recorded at the sites of Ramos Mexía Reservoir: S9 (18\%), S10 (41\%), and downstream of this reservoir, at S11 (11\%) (Fig. 5).

As regards the correlation coefficient calculated between the percentage abundance of each bacterial phylum at each site and the proportion between HNA and LNA abundance (HNA/LNA) at each site, for Bacteroidetes we obtained a correlation coefficient of $0.99(p<0.005)$ and for Actinobacteria a coefficient of $-0.86(\mathrm{p}<0.005)$. This indicated that higher proportions of HNA correlated with higher proportions of Bacteroidetes, while higher proportions of
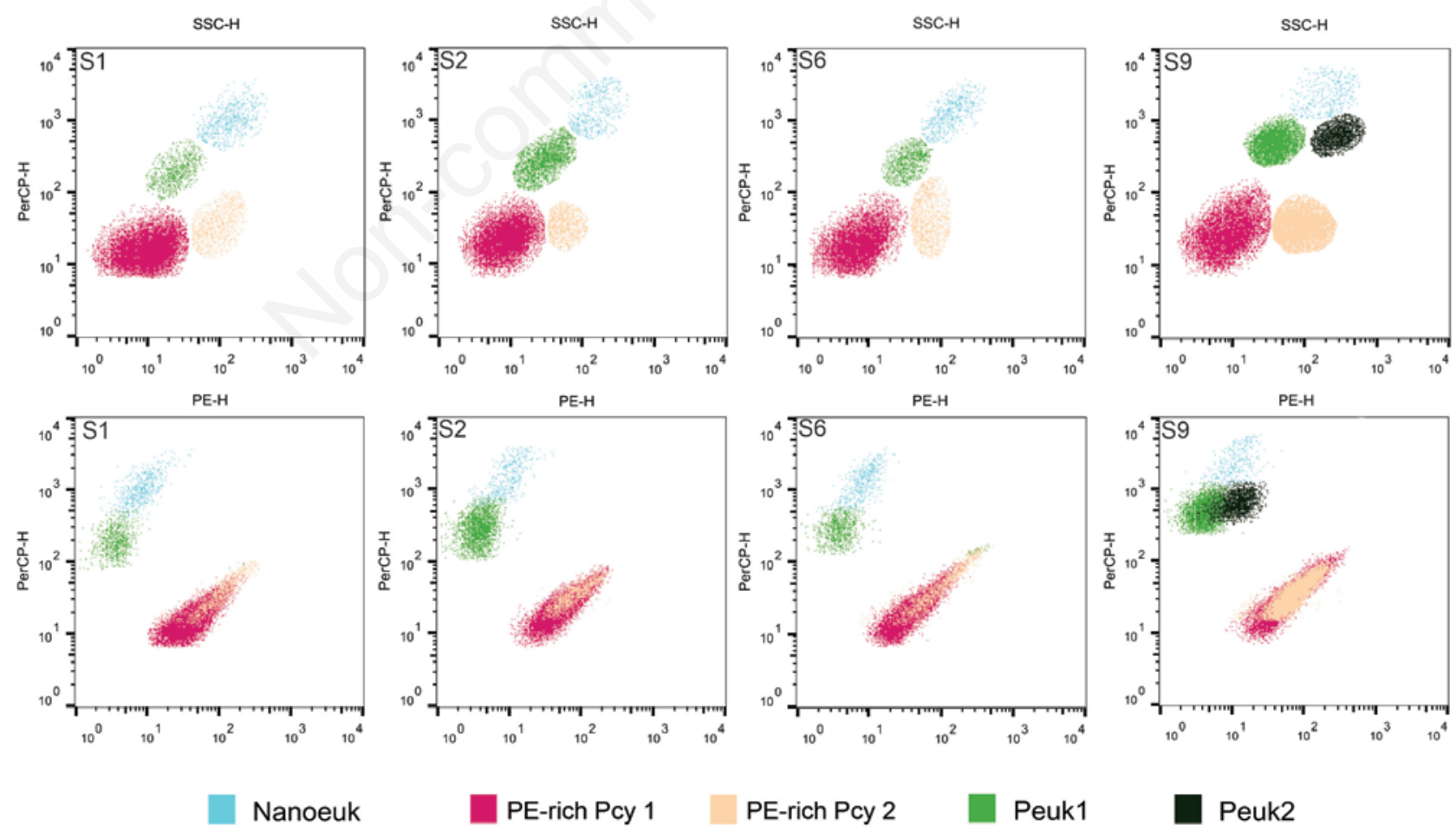

Fig. 4. Photosynthetic cytometric populations present at sites S1 (upstream of Alicura Reservoir), S2 (Alicura Reservoir), S6 (Piedra del Águila Reservoir) and S9 (Ramos Mexía Reservoir), shown in PerCP-H vs SSC-H and PerCP-H vs PE-H. Nanoeuk, Nanoeukaryotes; PE-rich Pcy, PE-rich picocyanobacteria; Peuk, Picoeukaryotes. 
LNA correlated with higher proportions of Actinobacteria.

The most frequent OTUs shared by all sites were represented by Actinobacteria of the following families: Sporichthyaceae, Ilumatobacteraceae and Microbacteriaceae (Rhodoluna genus). Proteobacteria were represented by three main OTUs taxonomically affiliated to Limnohabitans, Clade III and 'Candidatus_Methylopumilus'. The most frequent Bacteroidetes OTUs in CC comprised species corresponding to Flavobacterium, Fluviicola and Pseudarcicella genera (Supplementary material 1).

A clear spatial pattern in OTU richness was observed, with higher values at the lotic sections (Limay River) than at the reservoirs. Evenness exhibited the opposite spatial pattern, with higher values at the reservoirs (Fig. 6). S3 (Alicura Reservoir) displayed the lowest bacterial richness and S8 (Limay upstream of Ramos Mexía) the highest one (Fig. 6).

The NMDS analysis (Fig. 7) performed with the OTU composition of the sites (stress value $=0.09$ ) showed a spatial ordination in three main groups: S2 to S4, S6-S7 and S10-S11 which correspond to samples taken at or near Alicura, Piedra del Águila and Ramos Mexía reservoirs, respectively. S5 (located near the confluence of Collon Cura with Limay River) also grouped with S2 to S4. S1, upstream of Alicura Reservoir, ordinated closer to the S2 to S5 samples, whereas S9, at Ramos Mexía, ordinated in between the other two groups. S8, upstream of Ramos Mexía, and CC (Collon Cura) ordinated separately from the rest of the samples and from each other (Fig. 7).

The biplot of the RDA performed (bacterial OTU composition of samples and environmental variables) is shown in Fig. 8. The first two axes accounted for 56.4\% of the variance (axis 1: $43.0 \%$; axis 2: 13.4\%) and were statistically significant $(\mathrm{p}<0.01)$. $\mathrm{pH}$ was statistically significant $(\mathrm{F}=2.14, \mathrm{p}<0.05)$ and negatively associated with RDA1 (score=-0.55). DOC and conductivity were also statistically significant $(\mathrm{F}=3.44 \mathrm{p}<0.01 ; \mathrm{F}=1.32 \mathrm{p}<0.1$, respectively) and positively related with $\mathrm{RDA} 2$ (score $=0.78$, score $=0.83$, respectively). $\mathrm{TP}$ and $\mathrm{TN}$ were both statistically significant $(\mathrm{F}=1.88 \mathrm{p}<0.05, \mathrm{~F}=1.42$ $\mathrm{p}<0.1$, respectively) but with weaker relation with the axes. Turbidity positively associated with RDA2 (score $=0.75$ ), however was not significant. The ordination evidenced a clear spatial separation of the sampling sites. S1 (Limay, upstream of Alicura) and sites of Alicura (S2, S3, S4) were positioned together, towards lower values of turbidity, conductivity and DOC. S5 (confluence of Collon Cura with Piedra del Águila), S6 (Piedra del Águila) and S7 (Limay downstream of Piedra del Águila) were placed at an intermediate position, whereas S9, S10

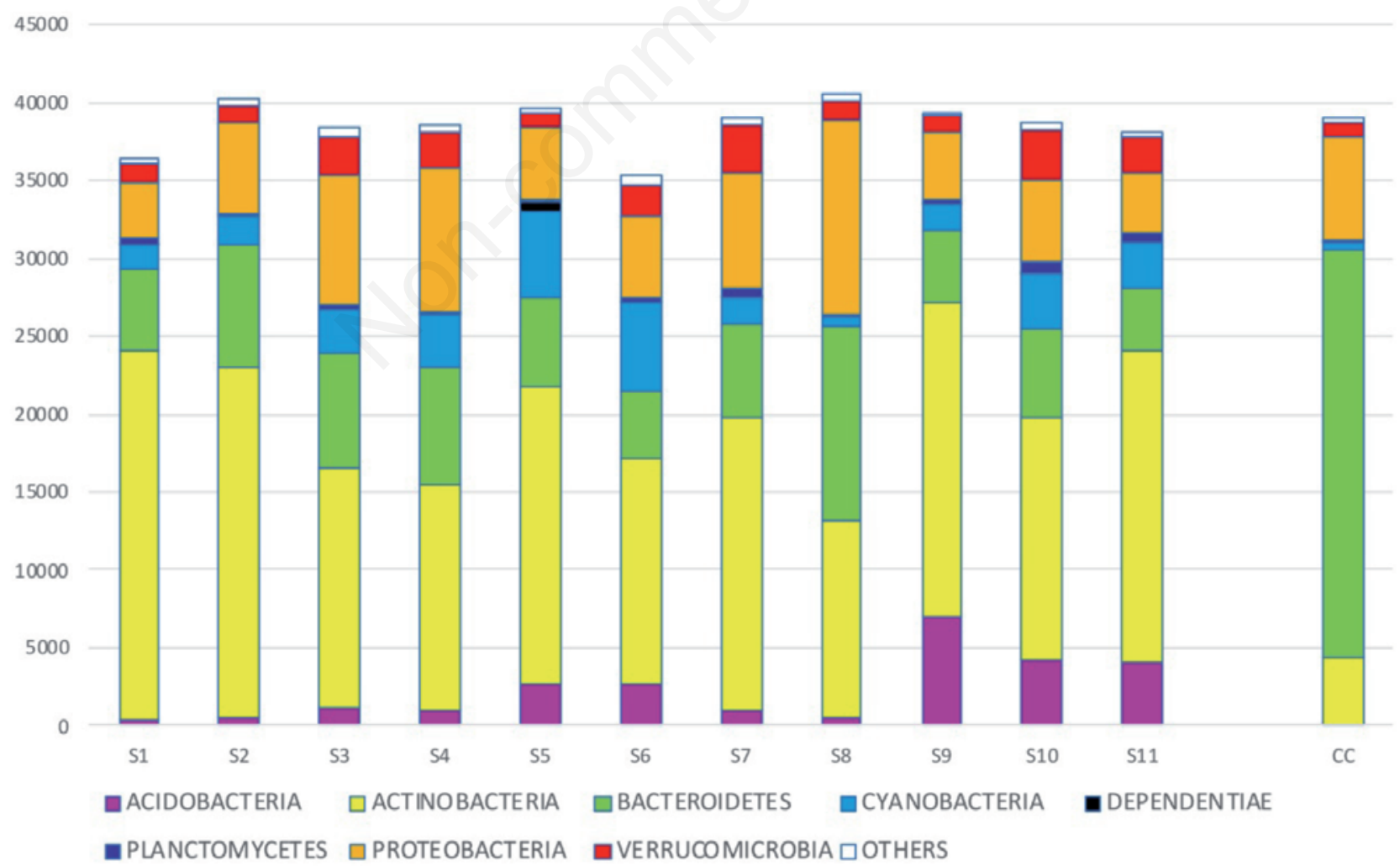

Fig. 5. Percentages of the dominant bacterial phyla at the 11 sampling sites in Limay River and at the site on Collon Cura tributary (CC), based on 16s rRNA gene sequences. 
(Ramos Mexía) and S11 (Limay downstream of Ramos Mexía) ordinated towards higher values of turbidity. S8 (Limay upstream of Ramos Mexía) and CC showed a separate position from the rest of the sampling sites and from each other. There is no clear ordination regarding the regime of each site (lentic or lotic).

\section{DISCUSSION}

The results of our study showed that, despite the eutrophication that usually occurs over time in impoundments, the Patagonian reservoirs of the Limay River remain in an oligotrophic or oligo-mesotrophic state, as was evidenced by Chl $a$ and nutrient concentrations. However, Ramos Mexía shows signs of a slightly more eutrophic condition. Also, local events of cyanobacterial blooms have been reported in littoral zones of the Ramos Mexía Reservoir in the last years (Labollita, 2011; Casco et al., 2014). Changes in the trophic state of reservoirs occur mainly in the early stages of the impoundment, when the terrestrial vegetation and soil are flooded (Baxter, 1977). Although the studied reservoirs are relatively old, the environmental characteristics of the region where they are placed (cold, relatively arid climate and still relatively low human-impacted catchments) probably account for their maintenance in an oligotrophic condition. In general, concentrations of nutrients (TN and TP) were relatively low, but at some sampling sites in our study we obtained higher values of TP than those reported previ- ously in the mid 90's (Díaz et al., 2007), with peaks clearly identified in S2, S6 and S7. In the case of S2 (Alicura), this might be explained by the presence of trout cages near the sampling site, which often add phosphorus to the water body from faeces and remains of food pellets; for this reservoir Temporetti et al. (2001) reported that after the fish farming installation (1992-1996), the area influenced by the fish farm showed an increase in TP and dissolved inorganic nitrogen concentrations due to the load from unconsumed food pellets and faeces. In the case of S6 (Piedra del Águila), it is worth mentioning that it is located in a recreational area of the reservoir near camping

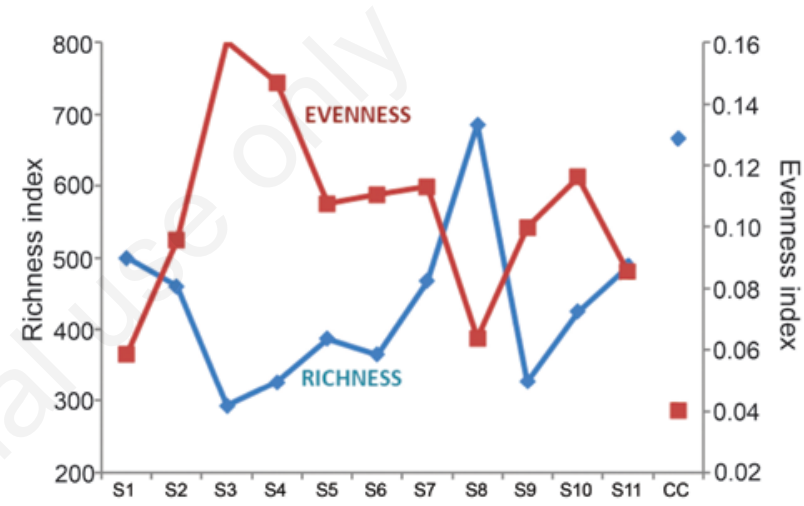

Fig. 6. Evenness and richness indexes calculated for each site based on bacterial OTU composition.

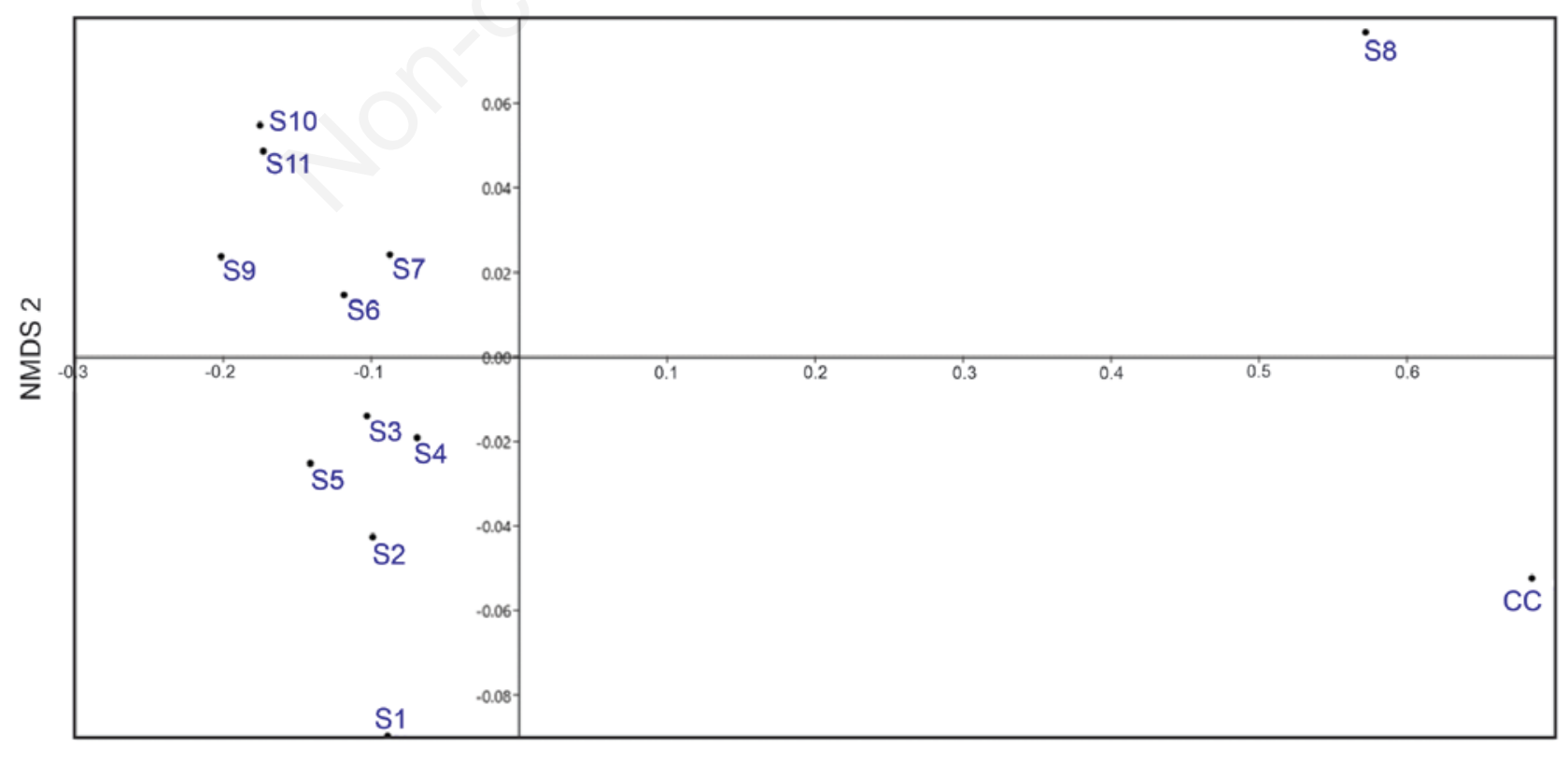

NMDS 1

Fig. 7. Non-Metric Multi Dimensional Scaling (NMDS) based on bacterial OTU composition of the sites. 
sites, so a possible phosphorus input from sewage present nearby cannot be discarded.

A clear spatial gradient was observed for some of the limnological variables measured, which seem to indicate an increase in eutrophication towards Ramos Mexía Reservoir. Indeed, turbidity, suspended solids and Chla increased in this direction. This pattern was also evidenced in the PCA performed. In agreement with our results, also low transparency values had been reported for this reservoir in previous studies (Mariazzi et al., 1991).

The increase in HB abundance that was observed towards Ramos Mexía is also indicative of a higher trophic state, according to the trends reported by Schiaffino et al. (2011) for a gradient of Patagonian lakes. On the other hand, the spatial pattern of HB abundance observed in the Limay system is similar to that described by Wang et al. (2018) for another cascade reservoir system, where bacterioplankton abundance was higher at reservoirs than at their downstream sites and at sites upstream of the first dam. In our studied system, the same pattern was observed when comparing values of $\mathrm{HB}$ abundance at Piedra del Águila Reservoir with that obtained at the downstream site, and at Ramos Mexía Reservoir with that obtained at the upstream site. Although we treated HB as composed basically by two types of cytometric populations (LNA and HNA), in most of the sampling sites more than one cytometric population within each one of these types was identified. The same was observed by other authors in flow cytometry analyses performed for other aquatic ecosystems (Bouvier et al., 2007; Schiaffino et al., 2013).

The slight increase in the Peuk fraction at Ramos Mexía Reservoir may also be related to the increase in trophic state in this direction, as several works have pointed out that the proportion of Peuk usually increases at higher turbidity and Chl $a$ values Pick and Agbeti, 1991; Vörös et al., 2009; Li, 2009; Schiaffino et al., 2013).

Our flow cytometry analyses revealed that in the Limay system Pcy are represented PE-rich cells, which is typical of transparent and oligotrophic water bodies. As was widely documented in the literature, the dominance of PE-rich or PC-rich Pcy in a given aquatic environment

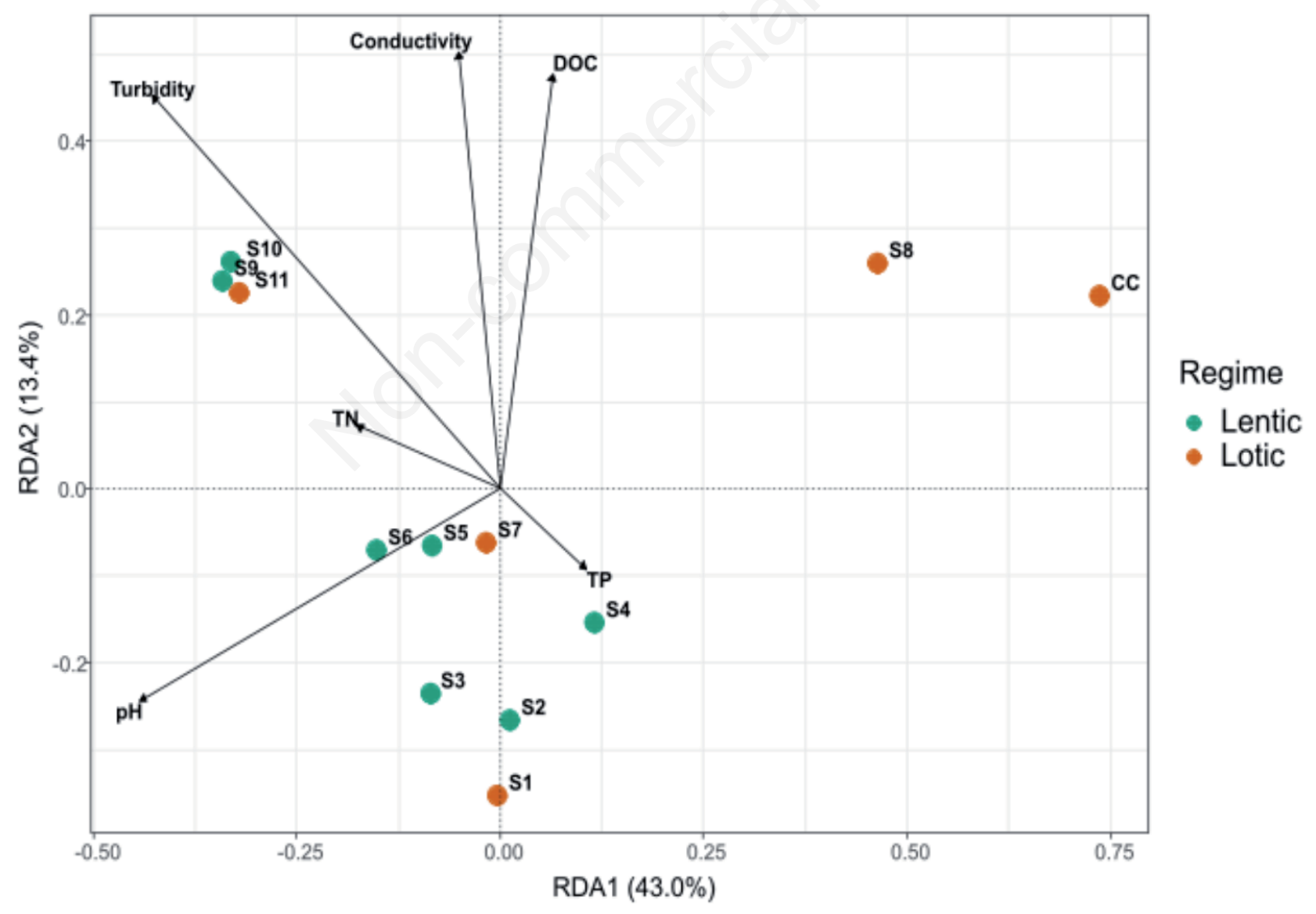

Fig. 8. Biplot of the Redundancy Analysis Analysis (RDA) based on bacterial OTU composition and environmental variables present at each site. Sites with lentic regime are represented in green and those with lotic regime, in red. DOC, dissolved organic carbon; TP, total phosphorus; TN, total nitrogen. 
is related to their capacity of exploiting distinct niches of the light spectrum due to their pigment characteristics. Thus, PC-rich Pcy prevail in more turbid and eutrophic lakes, whereas PE-rich Pcy are typical in more transparent and oligotrophic conditions (Pick, 1991; Callieri et al., 1996; Vörös et al., 1998; Stomp et al., 2007; Izaguirre et al., 2014; Porcel et al., 2019). The dominance of PE-rich Pcy in the Limay River system is in agreement with the results of a previous study carried out by Zunino and Díaz (2000) who reported a higher contribution of PE-rich Pcy in the oligotrophic water bodies studied, including Alicura and Ramos Mexía Reservoirs, using epifluorescence. In another study conducted by Schiaffino et al. (2013) in Patagonia that included many lakes of contrasting trophic states along a latitudinal transect, the relative contribution of PE-rich Pcy to total Pcy decreased towards increasing Chla gradients. Bastidas Navarro et al. (2009) also analyzed picoplankton structure in some North Patagonian lakes using epifluorescence and found that the community was dominated by PE-rich cells, but although PC-rich cells were much less abundant, in one of the studied lakes they increased slightly near the bottom. Thus, our results are in line with the previous reports of picoplankton structure in oligotrophic Patagonian lakes, where PE-rich Pcy are dominant. Nevertheless, we cannot discard the presence of PC-rich cells in low abundances, which were not detected by flow cytometry, particularly because we studied the upper layer of the water column.

The spatial pattern is also evident when analyzing the bacterial OTU composition along the system. The RDA showed that sites related to Alicura Reservoir ordinated towards lower turbidity and conductivity values, while sites related to Ramos Mexía Reservoir ordinated in the opposite direction. The NMDS revealed the same spatial pattern, clustering sites related to a reservoir separate from those related to another. Both analyses showed that S8 and $\mathrm{CC}$ ordinated far away from the rest of the sites and from each other, indicating their bacterial composition is different to that of most sites.

The dominance of Actinobacteria, Bacteroidetes, Proteobacteria, Cyanobacteria and Verrucomicrobia in the planktonic bacterial communities of the studied sites along the spatial gradient of the Limay River is in agreement with previous researches from other freshwater systems around the world (Newton et al., 2011; Tessler et al., 2017). Apparently, the members of these phyla are globally distributed (Tessler et al. 2017 and cites therein). The most abundant phylum at the main channel (Limay River) was Actinobacteria, a cosmopolitan Gram-positive bacterium (Ventura et al., 2007) that constitutes the dominant fraction of heterotrophic bacterioplankton (Newton et al., 2011; Lipko, 2020). This success in the studied oligotrophic system may be due to UV stress resistance, given by the high $\mathrm{G}+\mathrm{C}$ DNA content and possibly also due to their pigmentation (Hahn et al., 2003; Warnecke et al., 2005). Likewise, Bacteroidetes was the most abundant phylum in the Collon Cura River. Some members of this phylum are particle-associated bacteria (Nold and Zwart, 1998; Lemarchand et al., 2006) and seem to be involved in the degradation of complex biopolymers (Kirchman, 2002). Particularly, Flavobacteria, one of the dominant groups at $\mathrm{CC}$, is considered opportunistic, typical bloom specialists, favored by phytoplankton bloom derived exudates or decay products (Newton and McMahon, 2011; Sarmento and Gasol, 2012; Salcher, 2014). The high percentage of sequences of this group of Bacteroidetes at $\mathrm{CC}$ site could be explained by the resuspension of organic matter due to this being a lotic stretch of the system. The third most abundant phylum was Proteobacteria with Gammaproteobacteria class dominating in all sampling sites. S8 (upstream of Ramos Mexía) presented the highest proportion of these microbes compared to the rest of the studied sites and in the PCA it was ordinated towards higher values of TN, DOC and conductivity, indicating that their growth could be a result of allochthonous nutrient inputs, and the transport of bacteria from soil and sediment environments into that site of the Limay River. Limnohabitans genus dominated in this sampling site, as has been observed in other aquatic systems worldwide (Šimek et al., 2010; Props and Denef, 2020); this is a metabolically versatile, morphologically diverse bacterioplankton genus which plays an important role in funneling carbon from primary producers to higher trophic levels (Šimek et al., 2011, 2013; Salcher, 2014; Shabarova et al., 2017; Horňák et al., 2017). Interestingly, Acidobacteria, a phylum commonly found in freshwater sediments (Newton et al., 2011; Chang et al., 2020; Qin et al., 2021), showed the highest percentages at the sites of Ramos Mexía Reservoir (S9, S10) and downstream of this reservoir (S11). This is consistent with the highest turbidity and suspended solids values registered at this site.

The positive correlation obtained between the proportion HNA/LNA and Bacteroidetes, and the inverse correlation between HNA/LNA and Actinobacteria, is in line with the results obtained by Read et al. (2015) who compared the bacterioplankton structure from headwater tributaries with that of lower reaches of a river and found a higher proportion of HNA and Bacteroidetes at the headwater tributaries, and higher proportion of Actinobacteria and LNA at the lower reaches. Among the studied sites, S8 (upstream of Alicura Reservoir) and CC, both lotic, were the only ones where HNA dominated over LNA, and where Bacteroidetes equaled or exceeded Actinobacteria OTU abundances. As was pointed out by Wang et al. (2018), Bacteroidetes is an R strategist, more common in lotic systems, where there is a high input of "foreign" bac- 
teria to the system and competition is low. Contrarily, Actinobacteria is a $\mathrm{K}$ strategist, more common in lentic systems, where species sorting takes place and fewer taxa dominate. The pattern of richness and evenness obtained along the studied system may also be related to this, since lotic sites presented higher richness and lower evenness than lentic sites, whereas lentic sites showed the opposite pattern. In an extensive survey of bacterioplankton from 386 freshwater systems, Niño-García et al. (2016) reported that both hydrology and local water chemistry (mostly $\mathrm{pH}$ ) interact in structuring communities sequentially from highly diverse assemblages in headwater streams to fewer taxa dominating in larger rivers and lakes. They found that increases in water retention time along the hydrologic continuum were accompanied by substantial losses in bacterial richness and an increased differentiation of communities driven by local conditions, concluding that hydrology and network position modulate the relative role that environmental sorting and mass effects have on community structure by determining both the period of time for bacterial growth and the composition of the immigrant pool. Accordingly, in a cascade reservoir system Chen et al. (2020) found that spatial variables were more strongly correlated with rare bacterioplankton taxa than with abundant ones, and that the influence of environmental variables on bacterioplankton community assembly was stronger for abundant taxa than for rare taxa.

\section{CONCLUSIONS}

The results of our study confirm the first hypothesis postulated, since along this series of cascade reservoirs, together with a slight increase in trophic state downstream, an increase in picoplankton abundance towards the Ramos Mexía Reservoir was found. Contrarily, we could not confirm the second hypothesis because we did not find a change in the proportion of PE-rich and PC-rich Pcy as we expected; PE-rich Pcy dominated all along the system, at least in the upper layer of the water column. Regarding the bacterial composition, the molecular analyses confirmed the third hypothesis, as lotic and lentic sections of the system presented contrasting patterns of bacterial diversity.

This study constitutes the first spatial analysis of the autotrophic and heterotrophic picoplankton communities along the main cascade Patagonian reservoirs of the Limay River system. In contrast with most of the Argentinean reservoirs which are located in more human-impacted regions, these Patagonian impoundments are clearly less eutrophicated, and still exhibit microbial communities typical of oligotrophic environments. Nevertheless, the reservoir Ramos Mexía shows evident signs of a higher trophic state, and the trout production taking place in Alicura is a potential cause of eutrophication.

\section{ACKNOWLEDGEMENTS}

We wish to thank the Prefectura Naval Argentina from El Chocón, for the logistic support in the sampling at Ramos Mexía Reservoir. This study was financed with funds from a cooperation project between the Consejo Nacional de Investigaciones Científicas y Técnicas (CONICET, Argentina) and the National Natural Science Foundation of China (NSFC) - Project N ${ }^{\circ} 51861125204$.

\section{SUPPLEMENTARY MATERIALS}

Supplementary material 1: Bacterial OTUs obtained by Illumina MiSeq at the different sampling sites of the Limay system (summer 2019).

Supplementary material 2: Accession number of the samples from each site deposited in the European Nucleotide Archive (ENA) public database within the Project accession number ERP124551.

\section{REFERENCES}

Baffico GD, Pedrozo FL, 1996. Growth factors controlling periphyton production in a temperate reservoir in Patagonia used for fish farming. Lakes Reserv. Res. Manage. 2:243-249.

Baigún C, Marinone MC, 1995. Cold-temperate lakes of South America: Do they fit north hemisphere models? Arch. Hydrobiol. 135:23-51.

Bastidas Navarro M, Modenutti B, Callieri C, Bertoni R, Balseiro E. 2009. Balance between primary and bacterial production in North Patagonian shallow lakes. Aquat. Ecol. 43: 867-878.

Baxter RM, 1977. Environmental effects of dams and impoundments. Annu. Rev. Ecol. Syst. 8:255-83.

Bouvier T, Del Giorgio PA, Gasol JM, 2007. A comparative study of the cytometric characteristics of high and low nucleic $\square$ acid bacterioplankton cells from different aquatic ecosystems. Environ. Microbiol. 9:2050-2066.

Callieri C, 2008. Picophytoplankton in freshwater ecosystems: the importance of small-sized phototrophs. Freshwater Reviews 1: 1-28.

Callieri C, Amicucci E, Bertoni R, Vörös L, 1996. Fluorometric characterization of two picocyanobacteria strains from different underwater light quality. Int. Rev. Ges. Hydrobiol. 81:13-23.

Callieri C, Modenutti B, Queimalinos C, Bertoni R, Balseiro E, 2007. Production and biomass of picophytoplankton and larger autotrophs in Andean ultraoligotrophic lakes: differences in light harvesting efficiency in deep layers. Aquat. Ecol. 41:511-523.

Callieri C, Cronberg G, Stockner J, 2012. Freshwater picocyanobacteria: Single cells, microcolonies and colonial forms, p. 229-269. In: B. Whitton (ed.), Ecology of cyanobacteria: Their diversity in time and space. Springer.

CAMMESA, 2017. [Informe Anual]. [Document in Spanish]. Compañía Administradora del Mercado Mayorista Eléctrico. 
https://portalweb.cammesa.com/memnet1/Pages/descargas.aspx

Caporaso JG, Kuczynski J, Stombaugh J, Bittinger K, Bushman FD, Costello EK, Fierer N, Gonzalez Peña A, Goodrich JK, Gordon JI, Huttley GA, Kelley ST, Knights D, Koenig JE, Ley RE, Lozupone CA, McDonald D, Muegge BD, Pirrung M, Reeder J, Sevinsky JR, Turnbaugh PJ, Walters WA, Widmann J, Yatsunenko T, Zaneveld J, Knight R, 2010. QIIME allows analysis of high-throughput community sequencing data. Nat. Methods 7:335-336.

Caravati E, Callieri C, Modenutti, B, Corno G, Balseiro E, Bertoni, R, Michaud L, 2010. Picocyanobacterial assemblages in ultraoligotrophic Andean lakes reveal high regional microdiversity. J. Plankton Res. 32:357-366.

Casco MA, Labollita HA, Cano MG, 2014. Phytoplankton of the reservoirs of Central and North Patagonia. Adv. Limnol. 65:293-307.

Chang W, Sun J, Pang Y, Zhang S, Gong L, Lu J, Feng B, Xu R, 2020. Effects of different habitats on the bacterial community composition in the water and sediments of Lake Taihu, China. Environ. Sci. Pollut. R. 27:44983-44994.

Chen J, Wang P, Wang C, Wang X, Miao L, Liu S, Yuan Q, Sun S, 2020. Distinct assembly mechanisms underlie similar biogeographic patterns of rare and abundant bacterioplankton in cascade reservoirs of a large river. Front. Microbiol. $11: 158$.

Cotner JB, Biddanda BA, 2002. Small players, large role: Microbial influence on biogeochemical processes in pelagic aquatic ecosystems. Ecosystems 5:105-121.

Díaz MM, 1994. [Fitoplancton de lagos Andino-Patagónicos: su relación con factores abióticos]. [Doctoral dissertation in Spanish]. Facultad de Ciencias Exactas y Naturales, Universidad de Buenos Aires: 182 pp. http://digital.bl.fcen.uba.ar/ Download/Tesis/Tesis_2645_Diaz.pdf

Díaz MM, Temporetti PF, Pedrozo FL, 2001. Response of phytoplankton to enrichment from cage fish farm waste in Alicura Reservoir (Patagonia, Argentina). Lakes Reserv. Res. Manage. 6:151-158.

Díaz MM, Pedrozo FL, Reynolds C, Temporetti PF, 2007. Chemical composition and the nitrogen-regulated trophic state of Patagonian lakes. Limnologica 37:17-27.

Di Siervi MÁ, Mariazzi AA, Donadelli JL, 1995. [Medición de la producción bacteriana en un embalse patagónico. Variaciones espacio temporales y relaciones con la producción primaria]. [Article in Spanish]. Biología Acuática 18:33-42.

Dölling OR, 2013. [Inventario de presas y centrales hidroeléctricas de la República Argentina].[in Spanish]. Subsecretaría de Recursos Hídricos. Secretaría de Obras Públicas, Ministerio de Planificación Federal, Inversión pública y Servicios. Available from: http://www.energia.gob.ar/contenidos/archivos/Reorganizacion/contenidos_didacticos/publicaciones/LibroPresa s_4.pdf

Dudgeon D, 2020. Freshwater biodiversity: Status, threats and conservation. Cambridge University Press, Cambridge: $516 \mathrm{pp}$.

Edgar RC, Haas BJ, Clemente JC, Quince C, Knight R, 2011. UCHIME improves sensitivity and speed of chimera detection. Bioinformatics 27:2194-2200.

Fernández Zenoff V, Siñeriz F, Farias ME, 2006. Diverse responses to UV-B radiation and repair mechanisms of bacte- ria isolated from high-altitude aquatic environments. Appl. Environ. Microb. 72:7857-7863.

Gasol JM, Zweifel UL, Peters F, Fuhrman JA, Hagström A, 1999. Significance of size and nucleic acid content heterogeneity as measured by flow cytometry in natural planktonic bacteria. Appl. Environ. Microb. 65:4475-4483.

Hahn MW, Lünsdorf H, Wu Q, Schauer M, Höfle MG, Boenigk J, Stadler P, 2003. Isolation of novel ultramicrobacteria classified as Actinobacteria from five freshwater habitats in Europe and Asia. Appl. Environ. Microb. 69:1442-1451.

Herlemann DP, Labrenz M, Jürgens K, Bertilsson S, Waniek JJ, Andersson AF, 2011. Transitions in bacterial communities along the $2000 \mathrm{~km}$ salinity gradient of the Baltic Sea. ISME J. 5:1571-1579.

Hollander M, Wolfe DA, 1973. Nonparametric Statistical Methods. Wiley, New York: 503 pp.

Horňák K, Kasalický V, Šimek K, Grossart H-P, 2017. Strainspecific consumption and transformation of alga-derived dissolved organic matter by members of the Limnohabitans$\mathrm{C}$ and Polynucleobacter-B clusters of Betaproteobacteria. Environ. Microbiol. 19:4519-4535.

Izaguirre I, Unrein F, Modenutti B, Allende L, 2014. Photosynthetic picoplankton in Argentina lakes. Adv. Limnol. 6:343-57.

Kirchman DL, 2002. The ecology of Cytophaga-Flavobacteria in aquatic environments. FEMS Microbiol. Ecol. 39:91-100.

Kirk JTO, 1994. Light \& photosynthesis in aquatic ecosystems. 2nd Edition. Cambridge University Press, Cambridge: 509 pp.

Labollita HA, 2011. [Monitoreo de floraciones algales en las cuencas de los ríos Limay, Neuquén y Negro].[in Spanish]. IX Congreso de Ficología de Latinoamérica y el Caribe-VII Reunión Iberoamericana de Ficología-IX Simposio Argentino de Ficología: 50 pp.

Labollita HA, Pedrozo FL, 1997. Factors controlling trophic state of reservoirs at the basins of Limay, Neuquen and Negro Rivers (Argentina), p. 21-23. In: Proceedings 7th Int. Conf. on Lakes Conservation and Management: ILECLacar'97. International Lakes Environment Committee Foundation.

Lampert W, Sommer U, 2007. Limnoecology: the ecology of lakes and streams. Oxford University Press, Oxford: 324 pp.

Land de Castello H, 1981. [Algunos aspectos limnológicos abióticos de las cuencas de los ríos Limay y Neuquén, con especial referencia al embalse Ramos Mexia].[Article in Spanish]. Ecosur 8:1-27.

Lemarchand C, Jardillier L, Carrias JF, Richardot M, Debroas D, Sime-Ngando T, Amblard C, 2006. Community composition and activity of prokaryotes associated to detrital particles in two contrasting lake ecosystems. FEMS Microbiol. Ecol. 57:442-451.

Li WKW, 2009. Plankton populations and communities, p 2964. In: J.D. Witman and K. Roy (eds.), Marine macroecology. University of Chicago Press, Chicago.

Lipko IA, 2020. Phylogeny of the freshwater lineages within the phyla Actinobacteria (Overview). Limnol. Freshw. Biol. 358-363.

Mariazzi A, Conzonno V, Echenique R, Labollita H, 1991. Physical and chemical characters, phytoplankton and primary production of Ezequiel Ramos Mexía Reservoir (Argentina). Hydrobiologia 209:107-116. 
Marker AFH, Nusch A, Rai H, Riemann B, 1980. The measurement of photosynthetic pigments in freshwater and standardization of methods: conclusions and recommendations. Arch. Hydrobiol. 14:91-106.

McCartney MP, Sullivan C, Acreman MC, McAllister DE, 2000. Ecosystem impacts of large dams. Background paper 2.

McCully P, 2001. Silenced Rivers: The ecology and politics of large dams. Enlarged and updated edition. Zed Books, London \& New York: 360 pp.

Newton RJ, Jones SE, Eiler A, McMahon KD, Bertilsson S, 2011. A guide to the natural history of freshwater lake bacteria. Microbiol. Mol. Biol. R. 75:14-49.

Newton RJ, McMahon KD, 2011. Seasonal differences in bacterial community composition following nutrient additions in a eutrophic lake. Environ. Microbiol. 13:887-899.

Niño-García JP, Ruiz-González C, Del Giorgio PA, 2016. Interactions between hydrology and water chemistry shape bacterioplankton biogeography across boreal freshwater networks. ISME J. 10:1755-1766.

Nold SC, Zwart G, 1998. Patterns and governing forces in aquatic microbial communities. Aquat. Ecol. 32:17-35.

O'Farrell I, Motta C, Forastier M, Polla W, Otaño S, Meichtry N, Devercelli M, Lombardo R, 2019. Ecological metaanalysis of bloom-forming planktonic Cyanobacteria in Argentina. Harmful Algae 83:1-13.

Oksanen J, Blanchet FG, Friendly M, Kindt R, Legendre P, McGlinn D, Minchin PR, O'Hara RB, Simpson GL, Solymos P, Stevens MHH, Szoecs E, Wagner H, 2019. Vegan: Community Ecology Package. R package version 2.5-4. Available from: https://CRAN.R-project.org/package=vegan

Olson RJ, Zettler ER, DuRand MD, 1993. Phytoplankton analysis using flow cytometry, p. 175-186. In: P.F, Kemp, B.F. Sherr, E.B. Sherr and J.J. Cole (eds.), Handbook of methods in aquatic microbial ecology. Lewis Publishers, Boca Raton.

Pick FR, 1991. The abundance and composition of freshwater picocyanobacteria in relation to light penetration. Limnol. Oceanogr. 36:1457-1462.

Pick FR, Agbeti DM, 1991. The seasonal dynamic and composition of photosynthetic picoplankton communities in temperate lakes in Ontario, Canada. Int. Rev. Ges. Hydrobiol. 76:565-580.

Porcel S, Saad JF, Sabio y García CA, Izaguirre I, 2019. Microbial planktonic communities in lakes from a Patagonian basaltic plateau: influence of the water level decrease. Aquat. Sci. 81:51.

Porter KG, Pearl H, Hodson R, Pace M, Priscu J, Riemann B, Scavia D, Stockner J, 1988. Microbial interactions in lake food webs, p. 209-227. In: S.R. Carpenter (ed.), Complex Interactions in Lakes Communities. Springer, New York.

Press WH, Flannery BP, Teukolsky SA, Vetterling WT, 1988. Numerical Recipes in $\mathrm{C}-$ The art of scientific computing. Cambridge University Press, Cambridge: 735 pp.

Props R, Denef VJ, 2020. Temperature and nutrient levels correspond with lineage-specific microdiversification in the ubiquitous and abundant freshwater genus Limnohabitans. Appl. Environ. Microb. 86:e00140-20.b.

Qin Y, Tang Q, Lu L, Wang Y, Izaguirre I, Li Z, 2021. Changes in planktonic and sediment bacterial communities under the highly regulated dam in the mid-part of the Three Gorges Reservoir. Appl. Microbiol. Biot. 105:839-852.
Quirós R, Cuch S, Baigún C, 1985. [Relación entre abundancia de peces y ciertas propiedades físicas, químicas y biológicas, en lagos y embalses patagónicos (Argentina)].[in Spanish]. Taller Internacional sobre ecología y manejo de peces en lagos y embalses, Santiago de Chile.

R Core Team, 2018. R: A language and environment for statistical computing. R Foundation for Statistical Computing, Vienna.

R Core Team, 2020. R: A language and environment for statistical computing. R Foundation for Statistical Computing, Vienna.

RStudio Team, 2020. RStudio: Integrated Development for R. RStudio, PBC, Boston.

Rangel L, Silva LHS, Rosa P, Roland F, Huszar VLM, 2012. Phytoplankton biomass is mainly controlled by hydrology and phosphorus concentrations in tropical hydroelectric reservoirs. Hydrobiologia 693:13-28.

Read DS, Gweon HS, Bowes MJ, Newbold LK, Field D, Bailey MJ, Griffiths RI, 2015. Catchment-scale biogeography of riverine bacterioplankton. ISME J. 9:516-526.

Reis PC, Ruiz-González C, Crevecoeur S, Soued C, Prairie YT, 2020. Rapid shifts in methanotrophic bacterial communities mitigate methane emissions from a tropical hydropower reservoir and its downstream river. Sci. Total Environ. 748:141374.

Salcher MM, 2014. Same but different: ecological niche partitioning of planktonic freshwater prokaryotes. J. Limnol. 73:813.

Sarmento H, Gasol JM, 2012. Use of phytoplankton-derived dissolved organic carbon by different types of bacterioplankton. Environ. Microbiol. 14:2348-2360.

Schiaffino MR, Unrein F, Gasol JM, Massana R, Balague V, Izaguirre I, 2011. Bacterial community structure in a latitudinal gradient of lakes: the roles of spatial versus environmental factors. Freshwater Biol. 56:1973-1991.

Schiaffino MR, Gasol JM, Izaguirre I, Unrein F, 2013. Picoplankton abundance and cytometric group diversity along a trophic and latitudinal lake gradient. Aquat. Microb. Ecol. 68:231-250.

Schindler DW, 2006. Recent advances in the understanding and management of eutrophication. Limnol. Oceanogr. 51:356-363.

Secretaría de Energía, 2003. [Recursos hídricos: Centrales hidráulicas, embalses, lagos y lagunas].[Document in Spanish]. Secretaría de Energía, República Argentina: 136 pp.

Shabarova T, Kasalický V, Šimek K, Nedoma J, Znachor P, Posch T, Pernthaler J, Salcher MM, 2017. Distribution and ecological preferences of the freshwater lineage LimA (genus Limnohabitans) revealed by a new double hybridization approach. Environ. Microbiol. 19:1296-1309.

Sharp JH, Peltzer ET, Alperin MJ, Cauwet G, Farrington JW, Fry B, Karl DM, Martin JH, Spitzy A, Tugrul S, Carlson CA, 1993. Procedures subgroup report. Mar. Chem. 41:37-49.

Šimek K, Kasalický V, Jezbera J, Jezberov. J, Hejzlar J, Hahn MW, 2010. Broad habitat range of the phylogenetically narrow R-BT065 cluster, representing a core group of the betaproteobacterial genus Limnohabitans. Appl. Environ. Microb. 76:631-639.

Šimek K, Kasalický V, Zapomelová E, Horňák K, 2011. Algaderived substrates select for distinct betaproteobacterial lin- 
eages and contribute to niche separation in Limnohabitans strains. Appl. Environ. Microb. 77:7307-7315.

Stockner JG, Antia NJ, 1986. Algal picoplankton from marine and freshwater ecosystems: a multidisciplinary perspective. Can. J. Fish. Aquat. Sci. 43:2472 -2503.

Stomp M, Huisman J, Vörös L, Pick FR, Laamanen M, Haverkamp T, Stal LJ, 2007. Colourful coexistence of red and green picocyanobacteria in lakes and seas. Ecol. Lett. 10:290-298.

Temporetti PF, Alonso MF, Baffico G, Diaz MM, Lopez W, Pedrozo FL, Vigliano PH, 2001. Trophic state, fish community and intensive production of salmonids in Alicura Reservoir (Patagonia, Argentina). Lakes Reserv. Res. Manage. 6: 259-267.

Tessler M, Brugler MR, DeSalle R, Hersch R, Velho LFM, Segovia BT, Lansac-Toha FA, Lemke MJ, 2017. A global eDNA comparison of freshwater bacterioplankton assemblages focusing on large-river floodplain lakes of Brazil. Microb. Ecol. 73:1-14.

Valderrama JC, 1981. The simultaneous analysis of total nitrogen and total phosphorus in natural waters. Mar. Chem. 10:109-122.

Ventura M, Canchaya C, Tauch A, Chandra G, Fitzgerald GF, Chater KF, van Sinderen D, 2007. Genomics of Actinobacteria: tracing the evolutionary history of an ancient phylum. Microbiol. Mol. Biol. R. 71:495-548.

Vörös L, Callieri C, Katalin V, Bertoni R, 1998. Freshwater picocyanobacteria along a trophic gradient and light quality range. Hydrobiologia 369/370:117-125.

Vörös L, Mozés A, Somogyi B, 2009. A five-year study of autotrophic winter picoplankton in Lake Alaton, Hungary. Aquat. Ecol. 43:727-734.

Wang B, Liu CQ, Wang F, Yu Y, Zhang L, 2008. The distributions of autumn picoplankton in relation to environmental factors in the reservoirs along the Wujiang River in Guizhou Province, SW China. Hydrobiologia 598:35-45.

Wang X, Wang C, Wang P, Chen J, Miao L, Feng T, Yuan Q, Liu $\mathrm{S}, 2018$. How bacterioplankton community can go with cascade damming in the highly regulated Lancang-Mekong River Basin. Mol. Ecol. 27:4444-4458.

Ward JV, Stanford JA, 1983. The serial discontinuity concept of lotic ecosystems, p. 29-42. In: T.D. Fontaine III and S.M. Bartell (eds.), Dynamics of lotic ecosystems. Ann Arbor Science Publishers, Ann Arbor, Michigan.

Warnecke F, Sommaruga R, Sekar R, Hofer JS, Pernthaler J, 2005. Abundances, identity, and growth state of actinobacteria in mountain lakes of different UV transparency. Appl. Environ. Microb. 71:5551-5559.

Yang M, Shi J, Wang B, Xiao J, Li W, Liu CQ, 2020. Control of hydraulic load on bacterioplankton diversity in cascade hydropower reservoirs, Southwest China. Microb. Ecol. 80:537-545.

Zunino L, Díaz M, 2000. Autotrophic picoplankton along a trophic gradient in Andean-Patagonian lakes. Int. Ver. The. 27:1895-1899. 